\title{
THE FOURTH INTERNATIONAL POPLAR CONGRESS IN GREAT BRITAIN AND FOREST TREE BREEDING IN DENMARK \\ BY C. HEIMBURGER 1
}

The International Poplar Commission was founded in 1937 in France, to study all questions pertaining to the cultivation and use of poplars. Previous Congresses were held in France (1947), Italy (1948), Holland and Belgium (1949), and a meeting of the Commission only in Switzerland (1950) under the auspices of the F.A.O. of the U.N. Since the cultivation of poplars for other than decorative and shelter belt uses is in its infancy in Canada, it was deemed opportune to attend the Fourth International Congress, held in Great Britain in 1951, to establish contacts with other growers and breeders of poplars, and to gather information on silviculture and utilization which might be adapted to the conditions of this country. The interest in the growing of poplars for pulp and veneer and match stock is becoming evident by requests from several wood using industries for information about poplar cultivation. Although abundant published information on this subject of European origin is available, it has nevertheless been invaluable to see several cultural practices in operation and to discuss details with specialists in this particular field. The British Forestry Commission conducted a very well organized tour by bus through the southeastern part of England in connection with the Congress, with meetings at Oxford and in London. Seventy delegates from Austria, Belgium, Canada, Czechoslovakia, Eire, France, Germany, India, Italy, Lebanon, Netherlands, Spain, Switzerland, the F.A.O. of the U.N., and Great Britain attended. Notes for the tour were printed by the Forestry Commission in English, French and German, and contained such a wealth of valuable information about the places seen, that it was possible to go over a very large amount of material in the field during the relatively short time available. A map of the country traversed was also made available to the delegates as well as an album of photographs of the most noteworthy items of the tour. The congress opened in London on April 25th with a Government reception. During the following day a trip was made to the Forestry Commission Research Station at Alice Holt near Farnham, and to Kew Gardens. Then a round trip from London to Ipswich, Cambridge and Oxford, with stops at points of interest, was undertaken. The Congress ended on May 2nd with meetings at the Imperial Forestry Institute in Oxford, followed by a return trip to London.

During the tour poplar nurseries as well as plantations, maintained by the Forestry Commission, by private owners and by industrial concerns were visited and cultural practices discussed. Some other forms of forestry such as the growing and utilization of cricket bat willow and the maintenance of conifer nurseries and plantations were also seen. The following are the main points of interest of the tour:

I Southern Experiment Station, Department of Landa and Forests, Maple, Ontario. 
The Forestry Commission Forest Research Station at Alice Holt near Farnham contains a very large collection of poplars, mostly in the form of young plants and as stools for propagation of the most desirable clones. Some aspen hybrid materials from Denmark and from Canada are also grown there on a limited scale and tests for resistance to the European bacterial canker of poplars are in progress. A program of forest tree breeding has been started with a rather large number of tree species. Experiments in grafting and artificial hybridization are under way, but no breeding work with poplars. The nursery site is very unfavourable for the raising of tree seedlings, being a heavy, moderately acid ( $\mathrm{pH}$ 5.8), stony and poorly drained clay. Much work in improving it with the aid of various composts is being done. The method of raising poplars in current use has been adopted from Belgium, and most of the poplar clones grown for industrial purposes have been obtained from France, Belgium and Holland.

The poplars at Kew Gardens have been seen by me in 1923 and in 1937. Since then many new specimens of various species have been added to the collection, but they do not seem to thrive very well. The soil there is quite gravelly and root competition from the older trees seems to stunt the growth of many of the more recently planted specimens. Our native largetooth aspen is particularly unhappy here, on a site that is at times too wet for it, while some of the older poplar hybrids are represented by magnificent specimens.

On the way to Ipswich the English Timber Supply Co. (Essex) at Danbury was visited. The Company grows poplars for timber and specializes in the growing of cricket bat willow and the manufacture of cricket bats. A poplar display nursery is maintained in a very highly manicured condition, where plants are being grown for the Company's own use and for sale. The willows are raised for sets produced from stools.

The Fen Row Nursery in Rendlesham Forest is maintained by the Forestry Commission for the production of poplar plants and has some young poplar plantations immediately adjacent. The soil is largely muck on alkaline peat, something similar to the muck in the cultivated marshes near Bradford, Ontario. Poplars of the variety serotina show very good growth in such a soil, and a plantation 15 years of age has two sample plots. The number of trees per acre at this age is about 100, standing volume about 700 cubic feet per acre, total volume including thinnings about 1200 cubic feet per acre. Thus the total yield in terms of cubic feet per acre is rather low because of the low number of trees, but the trees have already reached sizes suitable for conversion into fruit baskets, have been pruned and are producing clear wood suitable for veneer in a not too distant future. The area is drained artificially by means of ditches and the humus layer is in an excellent state of decomposition with many nitrophilous plants in the ground vegetation. An understory of some muckloving tolerant tree species that could have increased the total yield and 
maintained a more favourable ecoclimate is noticeably lacking. But for a few stray bushes of elderberry, hawthorn and blackberries, the vegetation is entirely herbaceous. The absence of European ash and alder under these conditions is particularly noteworthy.

On the road from Ipswich to Cambridge the Ryston Hall Estate, the property of Lt. Col. E. R. Pratt, was visited. It contains a large poplar arboretum established before World War I with poplars imported from France and Germany, several of which are heavily attacked by the European bacterial canker while others have remained free from canker under the same conditions. The present owner became interested in poplars after many of the tree willows grown on his estate for the manufacture of fruit baskets succumbed to the shoestring fungus, and another tree suitable for growing on muck soil and producing wood suitable for fruit baskets, was needed. There is a good local market for baskets of this kind. The estate lies in part on muck soil over alkaline peat and in part on mineral soils of varying texture, probably old beach lines of a former lake before it was drained. The lower part of the area is drained artificially by pumping, as it is situated near sea level. Poplars, entirely of the cottonwood group, are grown mostly along roads, fence rows and in small plantations on odd pieces of land not suitable for agriculture. All the poplar material is set out as quite large plants, pruned almost since establishment and maintained in a very vigorous growing condition by frequent and heavy thinnings; frequent pruning favours the production of clear wood. The varieties doing best in the arboretum have been propagated and are now used for this purpose. One small plantation on moist mineral soil was planted with Chamaecyparis Lawsoniana which seems a good combination. It recalls natural stands of western cottonwood with an understory of western red cedar along the upper Columbia River in British Columbia, and suggests other possible mixtures of a similar nature that might be profitable in increasing the total yield and in maintaining a more favourable ecoclimate. The absence of watersprouts was noticeable on all poplars seen on this estate. This might have been caused by the very favourable growing conditions and in part be due to some manicuring prior to the visit of the delegates. The poplar variety robusta tends to suffer from sunscald and to develop frost cracks in unfavourable localities, just as it does in Canada. Another poplar stand was planted in mixture with ash, larch and spruce. As could have been expected, the larch and spruce did not fare well under such circumstances while the ash was of very poor growth form, and probably for this reason the plantation was not maintained by early and frequent thinnings. $A$ better strain of ash should have done considerably better under these conditions. English oak was in most cases the original tree species growing here, as evidenced by clumps of stump sprouts and old trunks found in the muck. After clear cutting the oak and its natural understory of various shrub species, poplar 
is planted at a wide spacing and usually maintained by frequent thinnings and pruning of all good trees. The former understory of the oak often reinvades such areas and tends to improve the ecoclimate for the poplars on muck soils. On mineral soils the understory tends to compete with the poplar for available moisture and probably should be restricted artificially to obtain the best results with the poplars. Rabbits are over-abundant everywhere, and all newly planted poplars and other trees are protected with wire netting around the base of the stem, just as in our young fruit orchards.

Another rabbit concentration was seen at Ling Heath, near Brandon, to the $\mathbf{N} \mathbf{E}$ of Cambridge. The area of about 180 acres consists of "breckland", chalk covered with sand, and now partly planted with Scots pine varying greatly in stem form. The soil has a weak podsol profile and supports a very scarce ground vegetation. The income from the rabbits is greater than from the Scots pine. A hat factory has been established in 1937 to utilize the fur of about 58 thousand rabbits killed during that year alone. On this area various poplars were planted after the first world war in an effort of afforestation by Brig. Gen. de Lotbiniere, an uncle of the present owner of the Seigniory of Lotbiniere at Pointe Platon, Quebec, the site of the blister rust resistant white pine plantation. The poplars are planted as sets and are, as a rule, not doing too badly considering the very poor soil and lack of moisture. Heavy infection by bacterial canker is evident and the area constitutes a good testing ground for poplars under adverse conditions. A clone of the variety Eugenei stands out here because of resistance to canker and relatively good growth. Aspen cf Polish origin was planted also, in the form of rooted plants, and is growing very slowly. Another area nearby, with slightly more fertile soil, has a very good plantation of Polish aspen with numerous suckers available for propagation. All the poplars here are so widely spaced that they do not form a closed stand and thus do not compete for moisture, a situation similar in this respect to the open stands of native cottonwood on the dry sandy unglaciated area of central Wisconsin. The chalk underlying the sand at various depths has most likely something to do with the relatively good growth of the poplars.

Near Ling Heath there are extensive plantations of Scots pine and Corsican pine in the Thetford Chase Forest. The growth form of Scots pine is often better than of the usual Ontario Scots pine, although there is still considerable room for improvement. Corsican pine seems to be a very promising species, also, for our conditions in southern Ontario. The growth form is generally very good, often surpassing that of our red pine; there is considerable variation in this respect as well as in foliage characters, and the species seems well adapted to soils with a high lime content.

At Lyndford Hall Forester Training School Mr. K. A. Sabet of the Botany School, Cambridge, gave a lecture covering his researches of the 
bacterial canker of poplars. The identification of the causal organism and methods of transmission of the disease described, are of basic importance to the testing of poplars for resistance by means of artificial inoculation. The slime which exudes from active cankers can be used for inoculation and in time gives rise to other active cankers. Inoculation with a pure culture of the causal bacterium did not produce true perennial cankers; filtered slime added to the pure culture of the causal bacterium gave successful inoculation. Nestern cottonwood and several other American balsam poplars have proven susceptible to this disease, as well as some cottonwood-European black poplar hybrids.

Yardley Chase Forest is on the road from Cambridge to Oxford and contains a large poplar trial area established by the Forestry Commission under rather difficult growing conditions. The area is a run-down oak forest on heavy upland clay. Through successive stages of coppicing and harvesting of the best oaks the area has gradually been degraded to brushland composed of some of the original understory of the oak forest. Poplars were at first set out after complete clearing of the brush while later plantings were made directly into the brush, with very little site preparation. This resulted in slow establishment and poor growth. Instead of cutting lanes through the bush as the Russians do when regenerating their degraded oak forests, only small holes were cut and large poplar plants set out in these on a very wide spacing. Root competition by the brush is quite pronounced and the poplars often die back at an early age and then produce numerous new sprouts from the stump, just as they do in Canada when planted under heavy root competition from grass. The area is otherwise very well suited to mechanical site preparation by means of heavy machinery if such were available. It should also lend itself well to the application of herbicides on a rather large scale prior to the establishment of a poplar plantation.

The Imperial Forestry Institute at Oxford was the place of meeting for the International Poplar Commission and Congress. During the two meetings a report by Dr. G. Houtzagers on his trip to North America in 1950 to study poplars, was of particular interest. The distribution of the different forms of native $P$. deltoides in the bottomlands of the Mississippi valley and their seral relationships were discussed in some detail. The subspecies angulata is the most southerly, but is found throughout the range of the species on moist areas. The subspecies missourriensis is more northerly in its distribution, gradually being replaced by the subspecies monilifera to the north. In Minnesota the subspecies monilifers is predominant. In relation to growing possibilities in Europe, it was concluded that selected clones of the subspecies angitlata could be grown throughout the range of poplar cultivation, on the moister sites. A brief statement of the growing conditions for the two native aspens of North America was also given. Professor R. Rol of the Forestry School at Nancy, France, then gave a paper on artificial poplar hybrids in U.S.A. studied during the same trip. The work of Dr. E. J. Schreiner and professor Ralph McKee was 
reviewed, and the results found to be very discouraging. Disease was found in nearly all poplar plantations and only one clone of $P$. Maximo-wiczii $x$ tricbocarpa planted at Rumford, Maine, had a few healthy trees. The reasons for the poor results were given as follows:

1. Crosses of cottonwoods with balsam poplars.

2. Selection of clones was made on too young plants on the basis of juvenile rate of growth and rooting capacity from stem cuttings.

3. The test areas were located on too poor soils, generally sandy soils not well suited to the growth of good cottonwood poplars.

4. The climate of Maine, where most test areas were seen, is too tough on this kind of poplars.

5. The competition between trees was too heavy because of close spacing and lack of early thinnings; competition between the planted and native vegetation is also very pronounced.

6. The parents of the numerous hybrids were insufficiently known as regards disease resistance and ecological requirements.

The work of Dr. Scott Pauley at Harvard Forest with ecotypes of the native cottonwoods and intraspecific hybridization was also mentioned. Of the poplar diseases found, Dotbichiza populea does not behave in quite the same way, as in Europe. It attacks only hybrids as a primary parasite, never native species. Septoria musiva is particularly destructive to $P$. berolinensis, which is in agreement with numerous observations in Canada. It was concluded that most primary poplar hybrids are in poor physiological condition (unbalanced), and hence very susceptible to disease. Several short papers on various other aspects of poplar growing were given. Of interest to Canada was the expressed desirability of participation in the Congress of distant countries and the proposed emphasis on aspen and white (silver) poplars and problems of utilization of poplar wood. Towards the end of the meeting $I$ was asked to give a short talk on the poplar situation in Canada.

Kennington Nursery near Oxford is run by the Forestry Commission and the main problem there is a so-called conifer sickness of the soil, something similar to the condition at our Orono nursery. Various means of remedying this are being tried out, such as crop rotation, application of weed killers, soil sterilization, organic manures, etc. The soil is quite silty and puddles badly when overwatered. Crust formation during periods of drought is also quite pronounced. Some experiments with vegetative propagation of aspens by means of woody cuttings treated with growth hormones are worthy of note. They were conducted in a closed coldframe heated by means of an electric cable and the medium was $25 \%$ vermiculite and $75 \%$ coarse sand. One hundred ppm. of indolylbutyric acid were applied to the cuttings in a 2-second dip. About two-thirds of the cuttings had roots after treatment during early April. The future development of these cuttings is as yet unknown. It must be remembered that Snow ${ }^{2}$ also obtained good rooting of woody aspen cuttings after

2 Snow, A. G. Jr. 1938. Use of indolebutyric acid to stimulate the rooting of dormant aspen cuttings. Journal of Forestry $36(6): 582-587$. 
hormone treatment, but that all his material later died in the propagation frame. Perhaps early transplanting of the rooted cuttings into sterilized soil might prove workable.

Bagley Wood, near the Kennington Nursery contains an experimental poplar plantation in a narrow valley on heavy clay soil underlying a layer of shallow muck. The poplars were planted some 10 years ago and now have heights ranging from $28 \mathrm{ft}$. to $51 \mathrm{ft}$. The variety gelrica from Holland is slightly crooked on the heavy soil here in contrast to better growth form on lighter soil. Several of the new Italian hybrids are also planted here, and one of these, No. 15A, looks very promising. Another, here designated as A.M. (Arnaldo Mussolini) is rather crooked and does not look promising. This last clone has been introduced into the Argentine and is said to be doing very well there. The plantation is very highly manicured and suffers from lack of favourable ecoclimate. In earlier days there was some frost damage causing cankers on the main stems, since then overgrown. A few scattered sprouts of black alder which would have been rather beneficial in this locality, have been carefully cut back.

On the way back to London from Oxford, a brief stop was made at Courtauld's research station, Maidenhead. The Company manufactures artificial silk and is interested in growing poplars to supply the cellulose for this. A few plants of five poplar clones from Germany were planted at a rather close spacing in a lawn near the main laboratory in 1947. Two of these are said to be Dr. Wettstein's hybrids, previously selected for high cellulose content. According to Dr. Wettstein their parentage is cottonwood and European black poplar, but they look very much like $P$. generosa, i.e. they must have western cottonwood, $P$. trichocarpa in their ancestory, and thus may not be true to type. Their growth in a lawn is excellent but it would be interesting to know what they would do under field conditions, particularly from the standpoint of pulp production.

Another stop was made at Eton College which has a park with some very large and old poplars, possibly some of the oldest of their kind in England. Some very good specimens of the variety serotina are worthy of note. They are rather limby as they have never been pruned, but have good straight stems and rapid growth on the rich soil near the river Thames.

\section{POPLAR GROWING IN ENGLAND}

It would serve a useful purpose to outline briefly the main methods of poplar cultivation in England based on observations made during this tour, and published information, mainly Forestry Commission Leaflet 27, Poplar Planting, 1948. As in Canada, most poplars, except those of the aspen group, are raised from stem cuttings. Because of the mild winter the cuttings are cut and prepared from the time of leaf-fall to February and then stored in sand in a sheltered spot for callusing, prior to setting out in early spring. Great care is taken in selecting the cuttings for size and quality. Only cuttings $3 / 8$ inch and thicker are used, the length varying from 8 to 9 inches. The spacing in the nursery is wider than with us, 
usually about 9 inches apart in rows $15^{\prime \prime}-18^{\prime \prime}$ apart. Because of careful selection and treatment of the cutting material, high inherent rooting capacity of the clones used, and wide spacing in the nursery, the cuttings are capable of producing very large plants, (usually 4 to $9 \mathrm{ft}$. in height during their first year) and to fully utilize the nursery space available. A far greater proportion of the cuttings prepared and planted in this manner produces suitable plants than with us, and the additional effort in selecting and caring for the cuttings seems to be well justified by the results obtained. Muck soil as seen in the Fen Row Nursery at Rendlesham, is not very well suitable for the rooting of cuttings, and the cuttings are planted in the heavier soil at Alice Holt and grown there for a year. As the heavy soil at Alice Holt makes the lifting of large plants difficult, the $0 / 1$ plants are moved to Rendlesham and grown there for another year or two. Usually the $0 / 1$ plants are cut back to the root during this operation, the tops being used for the production of new cuttings and the roots planted at a wider spacing, usually about $2 \mathrm{ft}$. $\times 3 \mathrm{ft}$., or $3 \mathrm{ft}$. apart each way in the nursery. The newly planted stumps sprout vigorously during the second summer and after the sprouts have become about 8 inches high, all but one selected shoot are removed. The remaining sprout develops into a very strong shoot, and the resulting plant with a 2 -year-old root and a strong 1-year-old shoot is the most commonly used material for setting out in plantations. It has a much heavier root system than our $0 / 1$ stock, can survive competition with tall ground vegetation more successfully and continue rapid growth without appreciable check after planting. Before setting out, some of the side branches are carefully pruned off with a sharp knife or secateurs. For planting along roads and canals large stock is produced by planting the $0 / 1$ stumps at wider spacing in the nursery and letting them stay there for 2 years instead of one. This gives very large plants. Their side branches are pruned before setting out, and great care is taken to preserve the leader throughout all operations of lifting, transportation and planting. On soil suitable for rooting of the cuttings and not too heavy for lifting, such as light loams, the cuttings are sometimes planted at the wider spacing of about $2 \mathrm{ft}$. $x 3 \mathrm{ft}$. cut back at the end of the first year, and the stumps left standing in the nursery for another year to produce one strong shoot, i.e. the plants are $0 / 2$ stock instead of $0 / 1 / 1$ stock, or $0 / 1 / 2$ stock. The lifting in England is done by hand and must be a rather difficult and expensive operation. It lends itself to mechanization, however. Through discussion with delegates it became evident that in a nursery in Holland a mechanical plant lifter is used for large poplar stock, produced for street planting and other uses. It consists of a stationary tractor with a winch pulling a U-shaped steel blade stretched between two wooden poles, thus resembling the seedling root pruner used at the Green Timbers Forestry Station in British Columbia for the production of root-pruned $0 / 2$ stock of Douglas fir used directly in field planting. Another poplar lifting contraption was seen in Denmark. It has the U-shaped steel blade directly attached to the lower front end of a tractor 
which moves along the rows while lifting the poplars. Wooden rollers are attached to the bottom of the tractor, to prevent injury to the tops of the poplars. This device is thus essentially similar to the lifting machine used in our Midhurt nursery for conifer transplants. In Germany the planting of large poplars is also somewhat mechanized in that the planting holes are dug by means of motorized post hole digger mounted on a wheelbarrow-like contraption and capable of self propulsion, like a garden tractor. The lifting is usually done in early spring, immediately before planting. Fall-lifting and heeling in for the winter is not common.

The greater proportion of poplar plants is set out in single rows along roads and water courses, or in small groups on land that is too wet for agricultural use, or used in shelter belts. The choice of site is considered very important and most failures with poplars in the past are attributed to unsuitable site. Under natural conditions cottonwoods and European black poplars, the ancestral forms of most of the cultivated varieties and clones, grow on rich alluvial soils along water courses. They can stand flooding during a considerable period in spring and early summer, but demand moving ground water and are very sensitive to competition from other vegetation. In cultivation poplars can be grown on a very wide variety of sites, ranging from heavy clays to sands and including muck soils, provided these are fairly moist but well drained and have moving ground water. Because of the very high rate of transpiration, older poplar plantations influence the height of the water table and the moisture regime of moist and wet sites during the growing season. The planting of poplars in an artificially drained marsh can in time contribute to the lowering of the water table in the marsh and make it more suitable for the growing of other crops.

Poplars are usually planted in pure stands and at a very wide spacing, varying from $12 \mathrm{ft}$. $\times 12 \mathrm{ft}$. to $24 \mathrm{ft}$. $\times 24 \mathrm{ft}$., deending on the variety used and on the site. Narrow-crowned varieties such as robusta and robusta-like clones of other varieties planted on rather wet sites are usually set closer together than broad-crowned varieties on rather dry sites, where competition for available moisture may become a limiting factor. The presence of natural understory of elderberry (Sambucus), hawthorn (Crataegus), alder (Alnus) and other shrubs in old poplar plantations creates a favourable ecoclimate and probably tends to retard the formation of epicormic branches after pruning. The mixed planting of poplars with Chamaecyparis Lawsoniana seen at the Ryston estate indicates that an admixture of a very shade-tolerant and moisture-loving conifer species yielding valuable wood is quite feasible in better utilizing the space. Mixtures of western cottonwood with western red cedar seen in natural stands in British Columbia indicate the feasibility of using Thuja species as an admixture in poplar plantations, but probably only on sites where there is abundant moisture available both for the poplars and for their understory. In planting on such a wide spacing, it is of course important that a very large proportion of the trees planted remains alive and the 
available space is adequately utilized by their rapid growth. This is achieved by the careful raising of planting material as outlined above and by careful preparation of the site for planting. On muck soils and similar wet sites mechanical working of the soil is not feasible with available equipment and most site preparation is done by hand. Squares are dug or hoed and mounds are put over the planted poplars. On drier sites ploughing is used, followed by cultivation to decrease competition with the ground vegetation. In dense coppice growth, such as was seen in the Yardley Forest, squares are prepared by removing all underbrush. Under our conditions it would have been easier to destroy all the brush by mechanical means followed by burning, and then to plant poplars on a thoroughly cleaned area. Since there is no demand for small sizes in poplars, thinnings are kept at a minimum, which again is in line with the wide spacing used. All the planted trees are pruned, at least every two or three years, or before the lower side-branches reach a thickness of one inch. The aim is to produce clear wood, and about one half of the total height of the tree is kept free of side branches. Various home-made tools are used in pruning, ranging from contraptions similar to a barking spade where the cut is made from below and to something similar to a pruning hook, where the cut is made from above. The tools are made of good hard steel so that the branches can be removed with a single clean cut. The cutting end of the tools is placed at an angle to the long handle which is often composed of several sections, to operate at varying heights. This makes for a better cut and is easier on the knuckles. In Belgium another type of pruning tool for poplars is said to be used. It consists of a fork of two prongs grooved on their inner sides. A sharp chisel is moved up and down between the prongs in the grooves by means of a rod inside the hollow handle. In this manner the branch to be cut is held between the prongs and removed by repeated pushing of the chisel from below. The hollow handle as well as the rod inside are composed of several sections which can be put together to allow pruning at any suitable height. There is no doubt that a multitude of similar tools is in existence and many more can be developed depending on local talent and gadgeteering propensities. The idea behind all this is to remove the branches with a clean cut with as little damage to the bark as possible. The use of pruning saw or shears is therefore not recommended. This state of affairs lasts until the poplars are about 35 years old when they are ready for the final cut. At that age the height is about $90 \mathrm{ft}$., and the yield is about $4000 \mathrm{cu}$. ft. per acre. It is so low beciause of the small number of trees per acre and the main advantage in poplar cultivation is the short time required to reach timber size. Nothing is as yet known about regeneration of poplar stands in England. On the Continent ash and black alder often replace poplar in plantations where they are at first retained as an understory. It is probable that Cbamaecyparis and Thuja, at first mixed with poplar on suitable sites, may form the final stand after the poplars are removed, and yield large dimensions of valuable wood for special purposes. The suckering habit is considered undesirable in the black poplars and is not relied upon in regeneration of poplar stands. The proper utilization of poplar wood is in its infancy. 
One of the uses of poplar wood is for matches and match boxes, besides the production of fruit baskets. On the Continent it is used for plywood also. Much progress is anticipated along these lines in the near future, however. Discussion was in progress all through the tour about the different clones and varieties used and about their proper nomenclature. The older poplar plantations are for the most part made up of broad-crowned varieties such as serotina and marilandica. More recently, narrow-crowned varieties such as robusta and robusta-like types tend to be favoured because of their better growth form and, therefore, possibly higher productivity. Resistance to bacterial canker is generally considered important in the choice of varieties. Very little is known as yet about the wood quality of the different poplar varieties and clones. Some are said to have more dark heartwood than others and to produce it at an earlier age. Relation of this to site is also probable, as well as to method of establishment and nursery production. The maintenance of standard clones in a pure and unmixed condition seems to be very difficult, and one of the most important functions of the Forestry Commission is to produce poplar cuttings true to name for sale to growers. In Germany a very elaborate system of registration of nurseries to ensure the production of stock true to name, is said to be established. The production of cuttings from shoots of planted cuttings in the nurseries rather than from stools established for the purpose of cutting production also tends to favour the mixing of clones and varieties when several are grown in a nursery, as the distinguishing features of the different varieties in their juvenile condition are quite obscure.

Aspen poplars are as yet not being grown to any extent in England. A delegate from Scotland told me that aspen plantations there were rather unsatisfactory because of poor growth form. Young hybrid aspens are being grown at Alice Holt, and in time these should yield sufficient material for setting out in plantations and supply pertinent information. At Alice Holt and the Kennington nursery, aspen seedlings are being cut back after one year's growth in the nursery and subsequently produce strong vigorous growth. As with the cottonwoods, such plants with a 2-year root and a 1-year top are preferred in planting out. The Polish aspens seen planted at Brandon Heath show promise of producing trees of good form and probably could produce valuable stands if established on more suitable sites. The excellent results obtained in Denmark and Sweden with suitable populations of hybrids between European and our trembling aspens could conceivably be duplicated in England. Some of our hybrids between silver poplar and large tooth aspen are being grown at Alice Holt and look very promising, although they are difficult to propagate from stem cuttings.

\section{APPLICATIONS IN ONTARIO}

Poplars of the cottonwood group are being grown by our Department, and rooted as well as unrooted cuttings are being distributed by our Division of Reforestation. The material is the so-called Carolina poplar. It is a mixture of clones, the main part being something that looks very much like the variety robusta grown in Europe; the other seem to be wild cottonwoods, prob- 
ably spontaneous seedlings originated in Norfolk County and from there distributed to our other nurseries. It would be well to re-select the material and to grow only one single good clone of the robusta-like variety for distribution purposes. We would then obtain a much better average growth form from our planted Carolina poplars than we have now. As the cottonwood. like admixtures have shown an inferior rooting capacity from stem cuttings compared to the robusta-like main component, we would also obtain better results in the nurseries by growing selected cuttings of the latter. It would also serve a useful purpose to introduce other narrow-crowned poplar clones of excellent growth form seen in England, such as the narrow-crowned clone of serotina and the canker-resistant narrow-crowned clone of Eugenei and to compare their performance here with the robusta-like component of our Carolina poplar. Since the latter clones are said to be resistant to the European bacterial canker, there is the additional factor of safety in case this disease may be introduced here in the future. Some of the better new Italian hybrids as well as the variety gelrica which is grown in Holland on sandy soils with a high water table, are already being grown at Maple, and material for further tests will be available in the near future. The main use of poplars is in windbreaks, shelterbelts and fencerows where they could well replace the spontaneous assortment of native tree species, and on suitable sites with proper care produce a considerable revenue. This is not forestry in the ordinary sense, but could be called a kind of arboriculture. It could provide some of our zone foresters that are interested mainly in conversation about conservation with ample new scope for indoor as well as outdoor activities and in the end contribute to better land use. The method in current use in England of raising $0 / 1 / 1$ poplar nursery stock or $0 / 2$ stock with tops cut back at the end of the first year could well be tried here in the production of planting stock for this particular purpose which requires large plants with a high percentage of successful establishment. Pruning tools could then be devised utilizing our native talent for this purpose, and this should then gradually produce good clear poplar wood as a side-line under the guidance of some of our zone foresters. The demand for clear poplar wood for match stock and for veneer is already at hand, and it would be the task of our Department to find out how to produce it as efficiently as possible, and then to demonstrate and to disseminate the gained information to all interested parties. Since the yield of wood in terms of cubic feet per acre per year in pure poplar plantations is only about twice as large as of an average woodlot in southern Ontario, it will, under ordinary circumstances, only be economical to establish pure poplar plantations if good clear wood is produced. We have sites such as the Holland marsh and fairly large areas of rich soil with a high water table in Kent and Essex counties that could well produce excellent stands of poplar. Such areas are usually growing valuable crops and will require intensive management if grown with poplars. For this purpose direct planting of large cuttings on well-prepared land at a spacing of about 8 to 10 feet each way, as practiced in the U.S., seems preferable to the European method. However, 
we could well profit from early and frequent thinnings and from intensive pruning to produce sound, clear wood. The growing of these poplars for pulpwood production only is not recommended. There would be no objection, however, to utilize tops and small trees removed in thinnings for this purpose. Also in this respect integrated utilization will have its advantages. The use of suitable strains of white cedar as an admixture in poplar stands on rich moist sites would also be worth trying in this connection.

Aspen poplar plantations were not seen to any extent on this trip to England for arriving at any definite conclusions about application in Ontario. It would seem that the method of growing aspen nursery stock from seeds practiced at the Kennington nursery would warrant being tried out here, especially their method of cutting back the plants after the first year in the nursery, to produce stock with a strong root system.

\section{FOREST TREE BREEDING}

Some work in forest tree breeding was seen at Alice Holt and during the subsequent visit to Denmark tree breeding was the main item of interest. At Alice Holt work with Corsican pine, larch, oak and beech, Douglas fir and Sitka spruce, Sycamore maple and ash deserves mention. The work was just started a few years ago and is in its infancy. Corsican pine is one of the most promising species in planting work, but does not fruit heavily. 'The problem of seed production resembles that of our red pine. In addition, selection of elite trees is in progress and grafting is being used for their propagation and testing. The grafting method in use is not very successful, and I was asked to demonstrate our method of grafting pines.

An early-flowering type of Japanese larch has been found, and it is now used as stock for other larches to induce early flowering. An attempt is being made to assemble all the old European larch trees from the Dunkeld estate in the form of grafts and then to test them for growth form and for combining ability with Japanese larch. In this manner it is hoped to propagate the most promising individuals for the establishment of seed orchards where, in mixture with Japanese larch, seed of Dunkeld hybrid larch could be produced on a large scale and of better average quality than the present seed material of this kind. Oak and beech are very successfully grafted outside, by the whip and tongue method, and relying on small dormant buds on the scions for all future growth. All the conifers are side-grafted using a very short cut, probably the cause of their rather mediocre results. All elite trees are marked on a map and at the present time about 12,000 grafts are made each year. Ash and sycamore maple are usually propagated by budding, which appears quite successful. The breeding work is considered very important as most of the planting is done with conifers that lack proper adaptation to the climate, show great variation in growth form and growth rate, and of which the seed of suitable strains is in very short supply. The hardwoods have been subjected to negative selection in woodlots for several centuries and are badly run down, especially in respect to growth form. There is ample scope to find good specimens all over the country, to bring them together in a testing area in the form of grafts and then to establish seed orchards 
with the best native and foreign material. A "curly" Sycamore maple is being propagated for its wood, just as we would appreciate the propagation of a selected type of birdseye maple. All outside grafting is done on large stock, established in the nursery for one year, and the grafts are then planted out in testing areas and seed orchards. Direct grafting on to established stocks in plantations is not done. The very mild winters allow grafting in coldframes and unheated greenhouses to begin very early in spring. Some of Dr. Riker's white pine, selected for resistance to blister rust in Wisconsin, have been grafted and set out in the nursery for further testing. A number of white pine planted in England appear to have survived the blister rust under conditions of heavy natural infection, and arrangements have been made to obtain scions from these, as well as scions and seed from selected Corsican pine in exchange for some of our white pine and poplar materials. The exchange of poplar cuttings with the Forestry Commission has been under way since before the war. Information on the resistance of some of our poplars to the European bacterial canker has been obtained and is of value to our popular breeding work, in case this disease should be introduced here in the future. We have also received cuttings of several new Italian hybrid poplars through the Forestry Commission, as direct importation of cuttings from Italy thus far has not been successful because of transportation difficulties. In recent years the Forestry Commission has been issuing an annual list of poplar clones in their possession and served as a clearing house in the exchange of new poplar varieties. In this manner some of our $P$. alba $x$ grandidentata hybrids have been distributed to several parts of the European continent. One example of the usefulness of such an exchange of poplar cuttings might be cited. During his graduate work at Harvard University, Dr. E. Chalmers Smith, now of Dalhousie University, produced some hybrids of western cottonwood and balsam poplar. He sent me the seedlings in bulk at the termination of his studies at Harvard, and the material was further selected for winter hardiness, growth form and growth rate, as well as resistance to Melampsora rust and rooting capacity from stem cuttings. Recently the Forestry Commission has been interested in western cottonwood and its hybrids, as they seem to be of particular value for plantings in Wales and Scotland, and cuttings of all the selected seedlings of Dr. Smith, together with other western cottonwood -material, were sent here. It now appears that several of the selected seedlings produced by Dr. Smith seem particularly well suited to the requirements of the Forestry Commission and are being extensively propagated and distributed for further tests. An example of applied forest tree breeding was seen in the nursery of the English Timber Supply Co. at Danbury. Individual trees of European ash have been selected in Holland for vigour and growth form as best suited for street and road planting. The type selected has a short straight stem and a broad, rounded crown that is resistant to wind; the plants are healthy and vigorous and preferably male so that they do not pollute their surroundings with seedlings. A number of such clones have been imported from Holland and found suitable for growing in the conditions of Danbury. These are propagated in the nursery by budding on to common ash stock, 
and the grafts sold to individual landowners for road planting. Later the Company will purchase ash logs of uniform size and quality which will demand a much higher price than ordinary mixed and unselected ash, and the landowners will have the joy of seeing uniform avenues of ash along their roads.

\section{DENMARK}

Of the seven days spent in Denmark, three days were devoted entirely to forest tree breeding. Dr. C. Syrach Larsen, who is in charge of forest tree breeding, is an old schoolmate with whom a very close co-operation in tree breeding matters has been in progress. He was able to take me around to the four principal tree breeding centers and show me the latest developments there.

The Forest Botanic Gardens at Charlottenlund near Copenhagen is run by the Royal Ag. and Vet. College and contains many venerable tree specimens that have been used in early hybridization work. Of special interest were two specimens of Pinus Strobus that have thus far been resistant to blister rust under conditions of rather severe infection. Two others are suspected of being natural hybrids of Pinus Strobus with Pinus Peuce, the Balkan pine. We have young plants raised from scions of these trees growing at Maple, and it was of considerable interest to see the original trees. The original tree of Populus vernirubens raised from a cutting of a hybrid raised by Professor Henry in Dublin, was also seen. Cuttings of this tree were once received by me and propagated at the Petawawa F.E.S. While of no particular merit in areas with a dry continental climate, this hybrid poplar has been doing extremely well on the coast of British Columbia ever since cuttings were sent there from Petawawa. Another interesting feature of the Forest Botanic Gardens are its lawns. During the spring these are covered with a dense carpet of flowers such as Anemones, Crocus, Daffodils, Primulas and others, and in summer these are succeeded by masses of daisies, bluebells and the like. The secret of all this is to let the grass with the flowers stand uncut until most of the flowering herbs are going to seed, then to cut everything with a scythe followed by close clipping with a lawnmower during late summer and fall. This gives the flowering herbs an opportunity to ripen and scatter their seed and the young plants to establish themselves under favourable light conditions during the latter part of the summer. A reasonably civilized attitude towards the picking of flowers and excessive walking on the lawns is also essential for the success of this kind of lawn management. This kind of lawn is very pleasing in a setting of old trees and flowering shrubs, is far less expensive to maintain than the usual closely clipped grass lawn and is free from the unsightly plantain, dandelions an other weeds because of the existing ecological conditions.

The new arboretum of the Royal Vet. and Ag. College is located at Hoersholm, outside of Copenhagen. It was established shortly before the last war, chiefly because the Forest Botanic Gardens was getting too filled up with large trees and because of the expropriation of some of its area to newly 
constructed railroads and highways. Most of the materials at the Forest Botanic Gardens were moved to the new arboretum in the form of seedlings, cuttings and grafts during the last war, and much new material has been assembled there since then. Some interesting pine hybrids are found there also, seedlings of a Pinus Griffitbii from the Forest Botanic Gardens have been raised, and among these are several natural hybrids with our eastern white pine and others whose exact paternity is as yet uncertain. They appear to be quite hardy, show some hybrid vigour and are thus far free from blister rust which is attacking some western white pine and limber pine planted nearby rather severely. The new arboretum is now also the principal center of tree breeding, and a fairly large staff is exclusively engaged in this activity. At the time of my visit, the pollination of larch was in full progress. This genus lends itself extremely well to grafting, induction of early flowering, establishment of seed orchards and the production of hybrid seed in several combinations. The most usual of these is the cross of European with Japanese larch, although others seem more promising for our conditions. Work with different types and strains of Douglas fir, a species that is becoming very important in Denmark, and with Sitka spruce and Sitka $x$ white spruce hybrids is also in progress. A new method of outside grafting of hard pines has been developed. It consists of cleft grafting just above a node during early spring. The scion is left unprotected and side-branches of the grafted node are left intact to feed the graft during the earliest stages. Later, the side-branches are cut off as the scion begins to show new growth. As at Alice Holt Lodge in England, most of the outside grafts are made on established stock in the nursery. Later, the successful grafts are moved into seed orchards or socalled "tree shows", where widely spaced individual grafts planted in rich soil are given the chance to show their inherent branching habit and growth form, undisturbed by competition from surrounding trees. In this manner inherent good growth form is detected and immediately utilized for breeding purposes. This is of particular importance, in work with beech and oak, the principal hardwoods where individuals with inherent good growth form are very rare because of the age-old man-caused deterioration through continued cutting and extermination of the best trees in their woodlands. Work with European ash is also in a fairly advanced stage, chiefly because this species, like the larch, lends itself very easily to all the main tree breeding manipulations, and some examples of excellent types of this tree were at hand. All the grounds in the nurseries as well as in the early stages of seed orchards and tree shows are kept cultivated by means of a rotary tiller, something similar to a roto-tiller, but of sturdier construction and capable of more rapid work than the former.

The main poplar breeding centre is at the Hellestrup nursery near Soroe. It is run by a private match factory that imports most of its aspen wood from Poland and establishes stands of hybrid aspens in Denmark to create a local supply of raw material for the future. The main hybrids are those of European aspen with our trembling aspen, in various combinations. The most recently produced hybrids have Polish aspen and $P$. tremuloides var. 
Vancouverensis from the west coast of British Columbia as their parents. Aspen pollen from northern Ontario has also yielded some very good hybrids. A rather elaborate array of greenhouses and coldframes keeps the production of aspen hybrids to a level of about thirty thousand a year, and these are sold to State and private forest districts to be raised into wood suitable for match stock, which the Company hopes to buy later for its own uses. The whole enterprise does not pay for itself directly, but is less and less in the red as the years go by, and much new valuable experience in producing and raising the hybrid aspens to the match stock stage is accumulating. The Company is quite confident that the enterprise will be a very profitable investment in the long run. Their experiences with our $P$. alba $\times$ grandidentata hybrids have been poor. After good rapid growth in the nursery, the hybrids stagnate in plantations, develop crooked stems and curly tops and look unpromising. Many are susceptible to Melampsora rust. The cause of this is mostly an unfavourable site, in that our largetooth aspen and its hybrids do not tolerate poor drainage and require moving ground water to a higher degree even than cottonwoods. Other causes may be climatic. A good, cheap method of raising aspen hybrids from seeds has not been found yet, but they are working on it. The latest stunt is to use sterilized soil in the transplanting of young aspen seedlings. We have tried this at Maple recently, and with the most spectacular results. After about a month's growth in sterilized soil the aspen seedlings are about three times as large as those raised in the same, but unsterilized soil. A series of photographs has been taken, showing the rather poor results obtained at first with pure European aspen of local origin and progressively better results with hybrids of $P$. tremuloides with $P$. tremula. The use of cottonwood poplars in Denmark is very limited, although there is ample scope for work with this tree also.

The Danish State Forests have recently established a seed production centre at Krogerup, to the north of Copenhagen. It consists of a seed extraction plant built along lines similar to our plant at Angus, but smaller, as the seed requirements of the Danish State Forests are considerably smaller than our seed requirements for reforestation. The extraction plant is surrounded by nurseries, seed orchards and other seed production units. The nurseries produce material for the establishment of seed orchards in various parts of the country, so as to diminish the risk of crop failures caused by local unfavourable weather conditions. Most of the pronising breeding material produced at Hoersholm is brought here and propagated on a rather large scale, tested and used for the production of seed in various ways, if found promising. Grafting is carried out in greenhouses and outside, according to mass-production methods, and stock for grafting is being raised in considerable quantities. A furrow-making machine, similar to a disc, is used in transplanting seedlings into compartments where they later are grafted. It works very well in rather heavy clay loam. The ground is prepared by ploughing and harrowing in the fall and needs only a light raking in the spring before the furrows are made with the machine. The seedlings are then set in the furrows, with or without the aid of transplant boards, depending on their size. The work with larch 
and ash is so far advanced that it is believed the existing seed orchards will be able to fill the entire seed requirements of all State Forests as soon as they come into full production. With other species the situation is not as promising, notably with beech and oak that do not lend themselves easily to grafting, start seed production rather late and of which relatively large seed quantities are required. Selected stands of such species are located throughout the country and designated for seed production. Arrangements are also made abroad to import certified seeds of these species harvested in selected and approved stands. Of the seeds stored in their vault, I was given a good portion of a new apomictic hybrid of European black alder and gray alder, called Alnus spuria and of possible use in this country, as in Denmark, as an admixture in poplar plantations to increase their total yield. 